Перепьолкіна О. О., olenaspr@gmail.com,ORCID ID: 0000-0001-5784-1490,

Researcher ID: F-4219-2019,

к.е.н., дои., доиент кафедри економіки, Львівський торговельно-економічний університет, м. Львів

\title{
ЕФЕКТИВНІСТЬ ЗАБЕЗПЕЧЕННЯ ФІНАНСОВОЇ СТАБІЛЬНОСТІ ЗАСОБАМИ МАКРОПРУДЕНЦЙНОЇ ПОЛІТИКИ НБУ
}

\begin{abstract}
Анотація. В статті розглянуто важливість забезпечення стійкості фінансових систем в умовах невизначеності, щзо спричинена світовою пандемією. Встановлено пріоритетність иілей цінової та фінансової стабільності у функціонуванні НБУ. Економічний зміст фінансової стабільності визначено як стан фінансової системи, за якого вона здатна належним чином виконувати основні функиії, такі як фінансове посередництво та здійснення платежів, а також протистояти кризовим явищам. Охарактеризовано зміст макропруденичійної політики НБУ, принцчипи ї̈ реалізаџії та інструменти макропруденційного регулювання, щчо використовуються для забезпечення стабільності фінансової системи. Акиентовано увагу на необхідності забезпечення контролю розрахунків, розкрито механізм та об'єкти оверсайта платіжних систем. Розглянуто спектр показників, щцо визначають фінансову стійкість, досліджено їх рівень в умовах застосування карантинних обмежень. Проаналізовано ефективність забезпечення фінансової стабільності Національним банком; встановлено, щзо ї̈ високу результативність досягнуто завдяки деактивації буферів капіталу, рекомендацій банкам утриматися від виплати дивідендів, створенню сприятливих регуляторних умов для реструктуризації кредитів, наданню банкам ліквідності у необхідни обсягах через стандартні інструменти рефінансування НБУ. Розкрито загрози фінансового сектору на підставі результатів стрес-тестування НБУ, досліджено ризики функиіонування банківської системи (кредитний ризик, ризик достатності капіталу, ризик ліквідності, юридичний ризик, валютний та ризик прибутковості). Виокремлено рекомендації щодо підвищення ефективності забезпечення фінансової стабільності для органів державної влади та банківських установ; наголошено на перспективних напрямах досліджень, серед яких підвищення рівня збалансованості грошової маси, вдосконалення параметрів функиіонування фінансово-кредитного сектору, детінізація грошово-кредитного сектору та протидія викликам глобалізації у грошово-кредитній сфері.
\end{abstract}

Ключові слова: фінансова стабільність, макропруденційна політика, монетарна політика, стрес-тестування, ризики банківського сектору.

Perepolkina O. O., olenaspr@gmail.com, ORCID ID:0000-0001-5784-1490,

Researcher ID: F-4219-2019,

Ph.D., Associate Professor, Associate Professor of the Department of Economics, Lviv University of Trade and Economics, Lviv

\section{EFFICIENCY OF ENSURING FINANCIAL STABILITY BY MEANS OF MACROPRUDENTIAL POLICY OF THE NATIONAL BANK OF UKRAINE}

\footnotetext{
Abstract. The article considers the importance of ensuring the stability of financial systems in the conditions of uncertainty caused by the global pandemic. The priority of the goals of price and financial stability in the functioning of the NBU has been determined. The economic meaning of financial stability is defined as the state of the financial system, when it is able to perform properly its basic functions, such as financial intermediation and making payments, as well as withstand crisis phenomena. The content of the NBU's macroprudential policy, the principles of its implementation and the tools of macroprudential regulation used to ensure the stability of the financial system are characterized. Thus, the need to ensure control of calculations is emphasized, the mechanism and objects of the oversight of payment systems are revealed. The range of indicators that determine financial stability is considered, their level in the conditions of application of quarantine restrictions is investigated. The efficiency of ensuring financial stability by the National Bank is analyzed; it is determined that its high efficiency was achieved due to the deactivation of capital buffers, recommendations to banks to refrain from paying dividends, creating favourable regulatory conditions for loans restructuring, providing banks with liquidity in the required amounts through standard NBU refinancing instruments. The threats of the financial sector are revealed on the basis of the results of stress testing introduced by the NBU, the risks of the banking system functioning are investigated (credit risk, capital adequacy risk, liquidity risk, legal risk, currency
} 
and profitability risk). Recommendations for improving the effectiveness of financial stability for public authorities and banking institutions are highlighted; emphasis is placed on promising areas of research, among which the increase of the level of money supply balance, improvement of the parameters of the financial and credit sector, de-shadowing of the monetary sector and response to the challenges of globalization in the monetary sphere.

Key words: financial stability, macroprudential policy, monetary policy, stress testing, risks of the banking sector.

\author{
JEL Classification: E52, E58, E59 \\ DOI: https://doi.org/10.36477/2522-1205-2021-63-09
}

Постановка проблеми. В умовах пандемії та світової економічної рецесії проблема стійкості фінансових систем набуває важливого значення. Провідну роль у забезпеченні фінансової стійкості відіграє центральний банк. Для цього він використовує потужний інструментарій макропруденційної політики, який дає можливість мінімізувати системні ризики і гарантувати надійність проходження розрахунків. Національний банк України активно впроваджує у свою регуляторну практику досвід реалізації макропруден-ційної політики центральних банків провідних країн світу. Однак питання вдосконалення макропруденційного інструментарію НБУ для досягнення фінансової стійкості системи як однієї 3 пріоритетних цілей регулятора потребує глибокого вивчення.

Аналіз останніх досліджень і публікацій. Дослідженням питань забезпечення фінансової стійкості і реалізації макропруденційної політики, 3окрема показникам, що оцінюють стійкість системи, інструментам макропруденційного впливу та їх еволюції присвячені праці таких вітчизняних вчених, як: О. Гудзовата, В. Коваленко, В. Міщенко, С. Науменкова, Л. Тищенко, А. Чайбок та ін. Однак не всі аспекти цієї проблеми з'ясовано та обгрунтовано. Фінансова система динамічно розвивається, 3'являються нові ризики, які порушують її стійкість, отже, інструментарій регуляторного впливу має постійно вдосконалюватися і бути адекватним викликам сьогодення.

Постановка завдання. Метою статті є обгрунтування основ забезпечення фінансової стійкості засобами макропруденційної політики та аналіз ефективності iii реалізації Національним банком України.

Виклад основного матеріалу дослідження. Забезпечення фінансової стабільності є однією 3 найбільш актуальних проблем у сучасній економіці. В умовах системної нестабільності та поглиблення взаємозалежності світових фінансових ринків необхідною $є$ розробка ефективних методів моніторингу фінансової стабільності держав, регіонів та окремих фінансових інститутів. Це дозволить своєчасно відстежити момент можливого настання фінансової кризи, здійснити ефективні заходи для виходу з неї та прийняти рішення щодо стратегії подальшого розвитку.

Національний банк як центральний банк України й особливий центральний орган державного управління сприяе фінансовій стабільності, допомагаючи фінансовій системі ефективно виконувати свої функції та бути стійкою до криз. Він вживає заходів, щоб звести до мінімуму ризики для всієї фінансової системи, та допомагає банкам протистояти системним ризикам. Основною функцією Національного банку $€$ забезпечення стабільності грошової одиниці України. У ході виконання своєї основної функції пріоритетним для Національного банку $є$ досягнення та підтримка цінової стабільності в державі, а також у межах своїх повноважень, сприяння фінансовій стабільності, в тому числі стабільності банківської системи. НБУ також сприяє дотриманню стійких темпів економічного зростання та підтримує економічну політику Кабінету Міністрів України за умови, що це не перешкоджає досягненню зазначених вище цілей.

Згідно зі Стратегією монетарної політики [1] НБУ для досягнення своєї пріоритетної цілі Національний банк використовує монетарний режим інфляційного таргетування. Застосування цього режиму дало змогу багатьом країнам знизити інфляцію до низького рівня та стабілізувати іiі, сприяючи таким чином стабільності їх національних валют. У свою чергу, низька та стабільна інфляція $\epsilon$ необхідною передумовою для макроекономічної стабільності та, відповідно, формування сприятливого середовища для забезпечення фінансової стабільності, високих і стійких темпів економічного зростання, низьких реальних і номінальних процентних ставок, низького рівня безробіття, а також підвищення інвестиційної привабливості України.

НБУ застосовує інструменти монетарної політики для цілей фінансової стабільності лише за умови, що системний ризик та ускладнення у функціонуванні фінансових ринків характеризуються суттєвим впливом на перспективи інфляції та економічної активності в країні [2].

Фінансова стабільність виступає важливим фактором ефективності монетарної політики, оскільки є передумовою належної роботи механізму монетарної трансмісії. Крім того, досвід фінансовоекономічних криз в Україні демонструє, що фінансова стабільність також є обов'язковою передумовою забезпечення стабільності національної грошової одиниці.

Одночасна реалізація Національним банком монетарної та пруденційної політики обумовлює потребу узгодження цілей із цінової та фінансової стабільності. Згідно зі Стратегією макропруденційної політики [3] забезпечення інфляційних цілей 


\section{Herald of Lviv University of Trade and Economics. Economic Sciences. № 63, 2021}

здійснюється застосуванням монетарного інструментарію, а цілей з фінансової стабільності - застосуванням інструментів макро- та мікропруденційного регулювання. Важливим у роботі НБУ є координація досягнення цілей, виконання функцій та використання інструментів.

Фінансова стабільність - це стан фінансової системи, за якого вона здатна належним чином виконувати основні функції, такі як фінансове посередництво та здійснення платежів, а також протистояти кризовим явищам [4]. Забезпечення фінансової стабільності передбачає моніторинг макроекономічних, політичних, ринкових, правових, соціальних та інших факторів, які можуть досить суттєво впливати на економічну стратегію учасників ринку. Стабільна й ефективна фінансова система $\epsilon$ необхідною умовою для розвитку економіки, оскільки в іiі основу покладено довіру 3 боку суспільства. Фінансовій системі можна надавати характеристику стабільної, коли вона ефективно перерозподіляє ресурси від власників заощаджень до інвесторів, здатна абсорбувати шоки без значних негативних наслідків, а фінансові ризики ретельно оцінюються та адекватно управляються. Сьогодні для переважної більшості центральних банків світу забезпечення фінансової стабільності $€$ одним із ключових завдань. Національний банк України не є виключенням у цьому питанні, він розвиває систему забезпечення фінансової стабільності з врахуванням зарубіжного досвіду.

Для забезпечення фінансової стабільності НБУ здійснює реалізацію макропруденційної політики. Вона спрямована на усунення або обмеження системних ризиків 3 метою запобігання кризам чи зменшення втрат від них. Основними принципами проведення макропруденційної політики є: незалежність, прозорість, превентивний підхід, передбачувана (раціональна) гнучкість, координація, пропорційність, уникнення регуляторного арбітражу, врахування національних особливостей.

У складі макропруденційних інструментів виокремлюють інструменти капіталу, ліквідності та інші [5, с. 328]. До інструментів капіталу належать контрциклічний буфер капіталу, буфер системної важливості, буфер системного ризику, буфер консервації капіталу та коефіцієнт левериджу. До інструментів ліквідності відносять коефіцієнт покриття ліквідністю та коефіцієнт чистого стабільного фінансування. До інших макропру-денційних інструментів належать встановлення граничного співвідношення розміру кредиту та вартості забезпечення, встановлення граничного співвідношення суми обслуговування боргу та доходу позичальника або загальної суми кредиту та доходу, підвищені вимоги до розкриття інформації.

Фінансова стабільність, окрім стабільності фінансової системи, передбачає й забезпечення контролю розрахунків. 3 метою забезпечення безперервного, надійного та ефективного функціонування платіжних систем Національний банк здійснює оверсайт платіжних систем. Механізм оверсайта $\epsilon$ системою методів та інструментів нагляду, які використовує центральний банк з метою досягнення якісних характеристик функціонування платіжно-розрахункових систем на основі організаційного, нормативно-правового та інформаційно-аналітичного забезпечення. Він включає:

- моніторинг платіжних систем;

- оцінювання платіжних систем на відповідність вимогам законодавства України та міжнародним стандартам оверсайта;

- надання у разі потреби вказівок та рекомендацій щодо вдосконалення діяльності відповідних систем та застосування до них заходів впливу (у разі порушення законодавства) [6].

Об'єктами оверсайта платіжних систем на сьогодні в Україні $є$ [7]: платіжні організації платіжних систем; учасники платіжних систем; оператори послуг платіжної інфраструктури (клірингові, процесингові установи та інші особи, уповноважені надавати окремі види послуг або здійснювати операційні та інші технологічні функції в платіжних системах).

Для оцінки фінансової стабільності важливим $€$ визначення здатності фінансової системи до мінімізації ризиків, що можуть спричинити макроекономічні, політичні, ринкові, правові, соціальні та інші фактори, а також аналіз динаміки розвитку окремих секторів ринку та функціонування учасників ринку, з'ясування їх взаємозв'язку і визначення взаємовпливу.

Фінансову стабільність вимірюють за допомогою спектра показників, таких як рівень непрацюючих кредитів в економіці, коефіцієнти боргового навантаження, співвідношення наданих кредитів до вартості застави та багатьох інших. Також для ïi оцінки використовують комплексні індикатори, які дозволяють виявити поточну ситуацію у фінансовому секторі, проте не дають прогнозу подальшого розвитку ситуації. Прикладом такого комплексного індикатора $€$ Індекс фінансового стресу (ІФС).

Національний банк ініціював формування Індексу фінансового стресу для України, щоб оцінити ступінь стресу в фінансовій системі країни та оцінити і порівняти його 3 довгостроковим історичним середнім показником. Індекс розраховується на основі щоденних даних. Методика розрахунку ІФС базується на методиках, що застосовуються в інших країнах, проте вона скоригована відповідно до особливостей фінансової системи України. Основною складністю $є$ наявність обмеженої кількості якісних високочастотних показників із тривалими періодами спостереження. Ще однією проблемою $є$ низька ліквідність деяких місцевих фінансових ринків; певні показники можуть різко та суттєво змінюватися, оскільки ринки дуже чутливі до зовнішніх та внутрішніх шоків [8, с. 9].

Для оцінки фінансової стабільності центробанки також вимірюють стійкість системи за різних сценаріїв (зокрема, шокових), вивчають фінансові зв'язки фінансових установ (з іншими фінансовими установами та клієнтами), проводять опитування банків та компаній. 
Український банківський сектор зараз проходить стрес-тест у режимі реального часу. Криза, що почалася від середини березня внаслідок світової пандемії, зачепила всі країни та їхні фінансові сектори. Проте попередні зусилля НБУ $з$ розчищення банківського сектору, впровадження міжнародно визнаних вимог до капіталу та ліквідності, регулярне стрес-тестування, ризикоорієнтований наглядовий підхід та спонукання банків до формування запасу міцності у сприятливі часи дали свої позитивні результати, оскільки банки увійшли в кризу у гарній формі.

Карантинні обмеження стали непростим випробуванням для фінансової стабільності країни загалом і банківської системи. Індекс фінансового стресу миттєво відреагував на запровадження таких обмежень. У березні 2020 р. він протягом двох тижнів зріс до найвищого рівня з 2015 року, удвічі порівняно зі значеннями початку року. Найбільше на березневе зростання вплинули девальвація гривні та невизначеність на ринку цінних паперів. Проте протягом другого півріччя ІФС не демонстрував волатильності й перебував на низькому рівні. Майже всі показники повернулися до значень, що спостерігалися до початку пандемії COVID-19, а за деякими зафіксовано історично низьке значення. Зокрема, ставки за депозитами $\epsilon$ найнижчими за весь час роботи банківського сектору, а депозити населення зростають, що свідчить про збереження довіри вкладників до банківського сектору [9].

Напрочуд вагоме значення мало те, що попередньо Національним банком було вирішено задавнені проблеми банківського сектору з пов'язаним кредитуванням, тому сьогодні ліквідність фінансових установ однаково висока і в гривні, і в іноземних валютах, а банківський сектор не є залежним від ситуації на міжнародних ринках капіталу. Висока ефективність та прибутковість фінансових установ дозволила їм самим генерувати капітал. Оскільки достатність капіталу в банків істотно перевищувала мінімальний рівень, то його надлишок вони використовували для поглинання кредитних збитків та для подальшого кредитування.

3 метою забезпечення балансу між збереженням фінансової стійкості банківського сектору та наданням тимчасових поступок у несприятливих умовах Національний банк задіяв весь інструментарій, який використовують центральні банки світу. Від самого початку кризи було деактивовано буфери капіталу, надано рекомендації банкам утриматися від виплати дивідендів. Також було створено сприятливі регуляторні умови для реструктуризації кредитів, фінансові установи йшли на поступки позичальникам у період карантинних обмежень. Крім того, НБУ надає банкам ліквідність у необ- хідних обсягах через стандартні інструменти рефінансування.

Високий запас міцності банків та вчасні дії регулятора мають позитивний ефект: банківські послуги надаються безперервно, вкладники не мають обмежень доступу до своїх рахунків, забезпечено безпеку роботи мережі. Відмінною ознакою у проходженні даної кризи порівняно 3 попередніми $є$ швидке відновлення зростання обсягів депозитів.

Основними загрозами для фінансового сектору $\epsilon$ зниження попиту на банківські послуги та погіршення якості обслуговування кредитів. Для якісної оцінки впливу цих загроз НБУ провів експресстрес-тестування банків, де дослідив вплив на капітал 26 банків несприятливого макроекономічного сценарію. Внаслідок тестування було встановлено, що поточна криза може призвести до порушення нормативів достатності основного чи регулятивного капіталу дев'яти банків, у двох фінансових установ капітал може стати від'ємним. Ці установи вже демонстрували негативні результати стрес-тестування в минулому, проте не вжили достатніх заходів для усунення проблем. Такі банки якомога швидше повинні реструктуризувати баланси та змінити бізнес-моделі, отримати докапіталізацію від акціонерів. Завдяки суттєвому зростанню капіталу та ефективності банків у докризовий період результати експрес-стрес-тестування 2020 р. кращі, ніж минулорічного стрес-тесту.

Високою була якість корпоративного кредитного портфеля банків, передумовою якої було дотримання ними загальноприйнятих стандартів кредитування впродовж останніх років. Незважаючи на те, що бізнесу в докризовий період вдалося сформувати запас міцності внаслідок підвищення прозорості і прибутковості, повністю уникнути втрат не вдалося. Карантинні обмеження, зниження внутрішнього та зовнішнього попиту та невирішені структурні проблеми у багатьох секторах мають помітний вплив на платоспроможність позичальників. Пропонуючи кредитні продукти, банки зобов'язані відслідковувати фінансовий стан боржника та враховувати його тимчасові фінансові труднощі. Завдання позичальників - ставати прозорішими в частині розкриття фінансової звітності та виходити 3 тіньового сегмента. У відновленні економічного зростання у посткризовий період ключова роль належатиме саме фінансовим установам.

Результатом дослідження ризиків функціонування банківської системи була побудова карти ризиків, серед яких кредитний ризик, ризик достатності капіталу, ризик ліквідності, юридичний ризик, валютний та ризик прибутковості. Їхню динаміку зображено на рис. 1. 


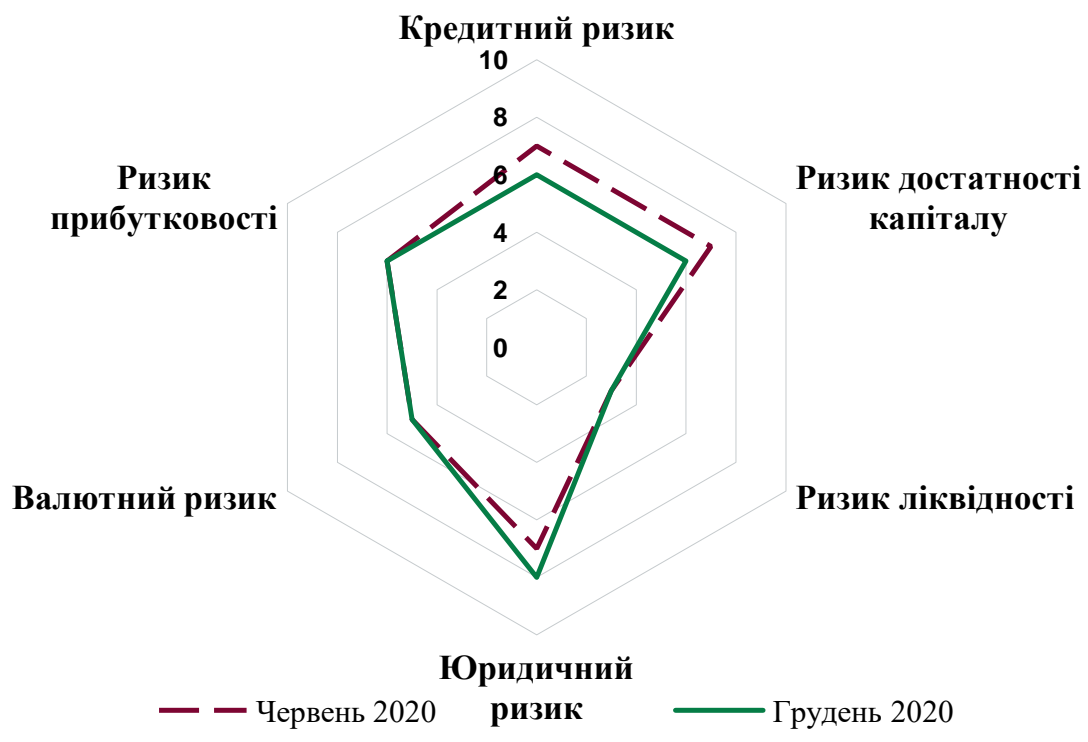

Рис. 1. Карта ризиків банківського сектору [9]

Оцінка ризиків здійснюється за шкалою від 0 до 10 , де 0 - це найнижчий ступінь ризику, а 10 найвищий. У другій половині 2020 р. кредитний ризик дещо знизився, хоча продовжував залишатися помірно високим. Він показує перспективи зміни рівня непрацюючих кредитів у портфелях банків та необхідність додаткового формування резервів під них. Причинами зниження кредитного ризику стали можливість банків гнучко проводити реструктуризацію кредитів позичальників, котрі мали тимчасові фінансові труднощі, та наявність державних програм підтримки бізнесу.

Зазнав послаблення і ризик достатності капіталу, він оцінює можливості банків забезпечувати достатній рівень капіталу. Його динаміку було забезпечено завдяки докапіталізації великого державного банку. Проте оновлені регуляторні вимоги до капіталу потребуватимуть від банків більш ретельного планування та управління капіталом.

Натомість ризик ліквідності, що демонструє здатність банків повною мірою та вчасно виконувати свої зобов'язання перед вкладниками і кредиторами, не змінився. Міцний запас ліквідності банків, яким вони володіли на початку кризи, дозволив швидко вгамувати панічні настрої. Проте зниження частки строкових вкладів може ускладнити управління ліквідністю.

Динаміка юридичного ризику нестійка. Він оцінює спроможність банків захищати власні інтереси за допомогою юридичних інструментів. Його зниженню у першій половині 2020 р. посприяло ухвалення закону щодо незворотності виведення банку з ринку [10]. Це суттєво знизило ризики для фінансової стабільності, оскільки відтоді неплатоспроможні банки не можуть повертатися на ринок, що унеможливило роботу “банків-зомбі”. Проте ухвалення суперечливих рішень Конституційного суду і судів загальної юрисдикції повернули негативну динаміку показника юридичного ризику в другій половині 2020 р.
Валютний ринок успішно пройшов випробування кризою, значної девальвації не відбулося, протягом місяця після початку кризи ситуація нормалізувалася. Як наслідок, валютний ризик, який вказує вплив тенденцій валютного ринку на фінансовий результат банків, не зазнав змін. Разом з тим, можливості інвестувати валютні кошти скорочуються, тому банки залишаються досить стійкими до можливих коливань курсу.

Ризик прибутковості також зберігає своє попереднє значення. Він свідчить про спроможність банків генерувати чистий прибуток. Зниження прибутковості банківської системи обумовлене падінням попиту на банківські послуги, яке частково може бути компенсоване підвищенням операційної ефективності.

До 1 липня 2020 р. в Україні було три фінансових регулятори: Національний банк, Нацкомісія 3 цінних паперів та фондового ринку та Нацкомфінпослуг. Закон України "Про внесення змін до деяких законодавчих актів щодо удосконалення функцій із державного регулювання ринків фінансових послуг” [11] передбачав так званий “спліт" ліквідацію Національної комісії 3 регулювання ринків фінансових послуг та розподіл повноважень 3 регулювання фінансового ринку між Національним банком та Національною комісією 3 цінних паперів та фондового ринку. Зокрема, НКЦПФР регулює недержавні пенсійні фонди та фонди фінансування будівництва, а Національний банк став регулятором страхових, лізингових, фінансових компаній, кредитних спілок, ломбардів та бюро кредитних історій. Оскільки багато учасників у цих сегментах недостатньо фінансово стійкі, НБУ ініціював впровадження на страховому ринку підходів до регулювання та нагляду, що грунтуються на пакеті законодавства ЄC Solvency. Це дозволить посилити ліквідність і плато-спроможність страхових компаній, покращити захист прав споживачів 
фінансових послуг та зміцнити конкурентне середовище.

Висновки i перспективи подальших досліджень у даному напрямі. Таким чином, Україна увійшла в поточну економічну кризу, спровоковану епідемією коронавірусу, із збалансованою макроекономічною ситуацією. Завдяки продовженню позитивної динаміки щодо послаблення інфляційного тиску Національний банк швидше пом'якшував монетарну політику та заклав передумови для суттєвого зниження вартості кредитів. Проте масштаби зниження економічної активності у 2020 році є значними, а відновлення може зайняти багато часу. Коронакриза припинила зростання реальних доходів населення, яке тривало протягом трьох останніх років. Визначальними чинниками цього стали зниження ділової активності внаслідок карантинних обмежень, зниження заробітної плати та зростання безробіття. Також суттєво погіршилися споживчі настрої, що сповільнило кредитування домогосподарств. Разом з тим, через скорочення доходу боргове навантаження домогосподарств зросло, що ускладнило обслуговування позик. Водночас макроекономічна нестабільність спровокувала підвищення схильності населення до заощаджень.

Основними засадами грошово-кредитної політики на 2021 рік та середньострокову перспективу передбачено, що діяльність Національного банку щодо підтримання фінансової стабільності спрямовуватиметься на підвищення стійкості фінансової системи до фінансових ризиків, що даватиме змогу підтримувати процеси економічного зростання за рахунок забезпечення ефективного перерозподілу фінансових ресурсів [12]. Це забезпечуватиметься шляхом стабілізації інфляційних очікувань, зваженої оцінки економічними агентами валютних ризиків, підвищення довіри до гривні разом із поступовою дедоларизацією економічних відносин, зростання довіри до банків та інших фінансових установ. НБУ планує здійснювати постійний моніторинг стабільності фінансової системи, використовуючи для оцінки ризиків кількісні та якісні індикатори, модельний інструментарій та професійне судження.

Для підвищення ефективності забезпечення фінансової стабільності необхідними є скоординовані зусилля всіх учасників фінансового ринку: НБУ, банків, небанківських фінансових установ та інших регуляторів. Вагоме значення має підтримка органів державної влади. Національний банк створює рекомендації для державних органів та фінансових установ.

До ключових рекомендацій для органів державної влади варто віднести наступне:

- забезпечити повноцінне виконання умов співпраці з міжнародними донорами;

- ухвалити закони, що сприятимуть розвитку фінансового сектору (про розширення переліку кредитних договорів, про Фонд часткового гарантування кредитів у сільському господарстві, зміни до Закону України "Про банки та банківську діяльність");
- оновити законодавство 3 регулювання небанківського фінансового ринку;

- посилити регулювання первинного ринку нерухомості; - прискорити реалізацію стратегії реформування державних банків.

Для забезпечення фінансової стабільності в умовах викликів, спровокованих світовою пандемією, основними рекомендаціями для банківських установ $є$ :

- здійснювати моніторинг макроекономічного середовища та стану окремих секторів економіки, а для планування показників діяльності покладатися на консервативні припущення та прогнози;

- підвищити оцінки очікуваних кредитних збитків;

- відслідковувати показники платоспроможності боржників 3 наступною оперативною реакцією; - активізувати роботу з непрацюючими кредитами;

- продовжити зниження депозитних ставок із урахуванням низької інфляції та зниження облікової ставки НБУ;

- продовжувати заохочувати перехід клієнтів до безготівкових розрахунків та безконтактного проведення операцій, забезпечуючи безперебійну роботу всіх необхідних сервісів;

- адаптувати бізнес-моделі до роботи в умовах кризи.

Досягнення очікуваних результатів у забезпеченні фінансової стабільності також вимагає підвищення рівня збалансованості грошової маси, вдосконалення параметрів функціонування фінансово-кредитного сектору, детінізації грошовокредитного сектору, протидії викликам глобалізації у грошово-кредитній сфері, що стане перспективними напрямами подальших досліджень.

\section{ЛІТЕРАТУРА}

1. Стратегія монетарної політики Національного банку України / Національний банк України [Електронний ресурс]. - Режим доступу: https://bank.gov.ua/ua/files/NUZWnbuLoRPDcNM.

2. Гудзовата О. О. Грошово-кредитна політика в системі забезпечення фінансової безпеки України: теоретико-методологічні засади та напрями реалізації : монографія / Гудзовата О. О. - Львів : Вид-во ННВК “АТБ”, 2018. - 300 с.

3. Стратегія макропруденційної політики / Національний банк України [Електронний ресурс]. - Режим доступу: https://bank.gov.ua/admin_uploads/ article/Strategy_MaP.pdf?v=4.

4. Офіційний сайт Національного банку України [Електронний ресурс]. - Режим доступу: http://www.bank.gov.ua.

5. Коваленко В. В. Моніторинг фінансової стабільності банківської системи України / Коваленко В. В., Радова Н. В. // Східна Свропа: економіка, бізнес та управління. - 2019. - № 2. - С. 321-330.

6. Положення про нагляд (оверсайт) платіжних систем та систем розрахунків в Україні : Постанова Правління НБУ від 28.11.2014 р. № 755 [Електронний ресурс]. - Режим доступу: 


\section{Herald of Lviv University of Trade and Economics. Economic Sciences. № 63, 2021}

http://zakon2.rada.gov.ua/laws/show/v0755500-

14/page.

7. Закон України “Про платіжні системи та переказ коштів в Україні" від 05.04.2001 р., № 2346-III [Електронний ресурс]. - Режим доступу: https://zakon.rada.gov.ua/laws/show/2346-14.

8. Тищенко Л. Індекс фінансового стресу для України / Тищенко Л., Чайбок А. // Вісник Національного банку України. - 2017. - № 240. - С. 5-14.

9. Звіт про фінансову стабільність. Грудень 2020. / Національний банк України [Електронний pecypc]. - Режим доступу: https://bank.gov.ua/ admin_uploads/article/FSR_2020-H2.pdf?v=4.

10. Закон України "Про внесення змін до деяких законодавчих актів України щодо удосконалення механізмів регулювання банківської діяльності” від 13.05.2020 р., № 590-IX [Електронний реcурс]. - Режим доступу: https://zakon.rada.gov.ua/ laws/show/590-IX\#Text.

11. Закон України "Про внесення змін до деяких законодавчих актів України щодо удосконалення функцій із державного регулювання ринків фінансових послуг” від 12.09.2019 р. №79/IX [Електронний ресурс]. - Режим доступу: https://zakon.rada.gov.ua/laws/show/79-20\#n208.

12. Основні засади грошово-кредитної політики на 2021 рік та середньострокову перспективу [Електронний ресурс]. - Режим доступу: https://bank.gov.ua/admin_uploads/article/MPG_2021 mt.pdf? $\mathrm{v}=4$.

\section{REFERENCES}

1. Stratehiia monetarnoi polityky Natsional'noho banku Ukrainy / Natsional'nyj bank Ukrainy, available at: https://bank.gov.ua/ua/files/ NUZWnbuLoRPDcNM.

2. Hudzovata, O. O. (2018), Hroshovo-kredytna polityka v systemi zabezpechennia finansovoi bezpeky Ukrainy: teoretyko-metodolohichni zasady ta napriamy realizatsii : monohrafiia, Vyd-vo NNVK “ATB”, L'viv, $300 \mathrm{~s}$.

3. Stratehiia makroprudentsijnoi polityky / Natsional'nyj bank Ukrainy, available at:
https://bank.gov.ua/admin_uploads/article/Strategy_Ma P.pdf?v=4.

4. Ofitsijnyj sajt Natsional'noho banku Ukrainy, available at: http://www.bank.gov.ua.

5. Kovalenko, V. V. and Radova, N. V. (2019), Monitorynh finansovoi stabil'nosti bankivs'koi systemy Ukrainy, Skhidna Yevropa: ekonomika, biznes ta upravlinnia, № 2, s. 321-330.

6. Polozhennia pro nahliad (oversajt) platizhnykh system ta system rozrakhunkiv v Ukraini : Postanova Pravlinnia NBU vid 28.11.2014 r. № 755, available at: http://zakon2.rada.gov.ua/laws/show/v075550014/page.

7. Zakon Ukrainy "Pro platizhni systemy ta perekaz koshtiv v Ukraini” vid 05.04.2001 r., № 2346III, available at: https://zakon.rada.gov.ua/ laws/show/2346-14.

8. Tyschenko L. and Chajbok A. (2017), Indeks finansovoho stresu dlia Ukrainy, Visnyk Natsional'noho banku Ukrainy, № 240, s. 5-14.

9. Zvit pro finansovu stabil'nist'. Gruden' 2020. / Natsional'nyj bank Ukrainy, available at: https://bank.gov.ua/admin_uploads/article/FSR_2020$\mathrm{H} 2$.pdf? $\mathrm{v}=4$.

10. Zakon Ukrainy "Pro vnesennia zmin do deiakykh zakonodavchykh aktiv Ukrainy schodo udoskonalennia mekhanizmiv rehuliuvannia bankivs'koi diial'nosti” vid 13.05.2020 r., № 590-IX, available at: https://zakon.rada.gov.ua/laws/show/590IX\#Text.

11. Zakon Ukrainy "Pro vnesennia zmin do deiakykh zakonodavchykh aktiv Ukrainy schodo udoskonalennia funktsij iz derzhavnoho rehuliuvannia rynkiv finansovykh posluh” vid 12.09.2019 r. №79/IX, available at: https://zakon.rada.gov.ua/laws/show/7920\#n208.

12. Osnovni zasady hroshovo-kredytnoi polityky na 2021 rik ta seredn'ostrokovu perspektyvu, available at: https://bank.gov.ua/admin_uploads/ article/MPG_2021-mt.pdf?v=4.

Стаття надійшла до редакиії 17 квітня 2021 року 